\title{
PROPERTIES AND MORPHOLOGY OF BARLEY EMBRYO ACETYL COA CARBOXYLASE
}

\author{
by \\ KAYE BROCK \\ C. GAMINI KANNANGARA \\ Department of Physiology, Carlsberg Laboratory \\ Gamle Carlsberg Vej 10, DK-2500 Copenhagen, Valby \\ and \\ Institute of Genetics, University og Copenhagen \\ $\emptyset$ ster Farimagsgade 2A, DK-1353 Copenhagen K
}

Key words: Acetyl CoA carboxylase, Barley embryos, Biotin carboxyl carrier protein

Acetyl $\mathrm{CoA}$ carboxylase was isolated and purified from barley embryos. The purified enzyme fixed $\mathrm{CO}_{2}$ at the rate of 7 to $7.4 \mu$ moles per min per $\mathrm{mg}$ protein. It had a molecular weight of 610000 daltons and one mole of biotin per mole of enzyme. The purified enzyme aggregates during sepharose $6 \mathrm{~B}$ gel filtration. Aggregation of the enzyme can be prevented by using $1 \%$ sodium chloride in the elution buffer. The biotin carboxyl carrier protein of the enzyme was identified as a small polypeptide with a molecular weight of 21000 daltons. This peptide behaves identically to barley chloroplast biotin carboxyl carrier protein during polyacrylamide disc electrophoresis in phenol: acetic acid: urea. The morphology of purified acetyl CoA carboxylase was studied by electron microscopy using a negative staining technique. This enzyme is a globular protein with a size of $275 \pm 8$ $\AA \times 192 \pm 42 \AA$ and displays characteristic cavities.

\section{INTRODUCTION}

Acetyl CoA carboxylase catalyses the formation of malonyl $\mathrm{CoA}$ from acetyl $\mathrm{CoA}$ and bicarbonate. This enzyme has been extracted and examined in animal tissues $(15,6,7,21)$, microorganisms $(1,16)$, and higher plants $(8,10$, 11). The acetyl CoA carboxylase obtained from liver tissues has a molecular weight of $7.8 \times 10^{6}$ daltons. In its active form the enzyme is filamentous. These filaments are made up of homogeneous subunits of molecular weight 410000 daltons (17). In higher plants, the enzyme was first demonstrated in wheat germ (8). It was later obtained in an over 1000 fold purified form and was shown to have a molecular weight of $630000 \pm 25000$ daltons (10). Wheat germ acetyl CoA carboxylase is a soluble protein which separates into two 
protein components, with $S_{w_{20}}$ values of $7.3 \pm$ 0.6 and $9.4 \pm 0.6$, during analytical ultracentrifugation. Acetyl CoA carboxylase has also been investigated in photosynthetic tissues $(11,12)$. The enzyme in chloroplasts resembles the carboxylase of Escherichia coli $(1,2)$ where the enzyme is made up of three easily separable proteins, biotin carboxyl carrier protein, biotin carboxylase and transcarboxylase. In $E$. coli all three components of the enzyme are present in the soluble fraction of the cell. By contrast biotin carboxyl carrier protein of the chloroplast enzyme is localized in the insoluble membrane fraction $(11,12)$. We investigated acetyl CoA carboxylase of barley embryos with the aim to determine the nature and location of biotin carboxyl carrier protein in this enzyme. The present communication presents evidence that barley embryo acetyl CoA carboxylase is closely similar to the wheat germ enzyme. Barley embryo carboxylase is morphologically different from the enzyme obtained from liver tissues. The biotin containing polypeptide of the soluble embryo enzyme appears to be similar to the membrane bound chloroplast biotin carboxyl carrier protein.

\section{MATERIALS AND METHODS}

\subsection{Isolation of Embryos}

Seeds of barley, cultivar Tern were dehusked essentially as described previously (3). Seeds were soaked in $50 \%$ by vol. sulphuric acid at $25^{\circ}$ for 2-3 hours with periodic stirring after which time the seeds were washed thoroughly in cold water to remove all traces of acid and husk fragments. Any remaining acid was neutralized by soaking the grain in ice cold water containing $\mathrm{CaCO}_{3}\left(50 \mathrm{~g} \mathrm{CaCO}_{3} / \mathrm{kg}\right.$ seed $)$ for $30 \mathrm{~min}$. The grain was then washed to remove $\mathrm{CaCO}_{3}$. During this washing, the seeds were rubbed together and against the wall of the container to loosen adhering husks. Washing was continued until no further husk fragments were released from the grain.

Dehusked barley seeds were germinated on damp filter paper for 16-24 hours. Subsequent isolation of embryos was as described by MURPHY AND BRIGGS (18). The isolated embryos were washed with $0.1 \mathrm{M}$ potassium phosphate buffer $\mathrm{pH} 8.3$ and stored frozen at $20^{\circ}$.

\subsection{Extraction and Purification}

Two methods were employed for extraction and purification of barley embryo acetyl CoA carboxylase. The first procedure has been described in detail by HEINSTEIN and STUMPF (10). Only the second procedure will be described here. The embryos were homogenized in $55 \mathrm{mM}$ imidazole-HCl buffer $\mathrm{pH} 8.3 \mathrm{con}$ taining $1 \mathrm{mM}$ dithiothreitol. The homogenate was filtered through mira cloth and centrifuged at $30000 \mathrm{~g}$ for $20 \mathrm{~min}$ in a Sorvall centrifuge. Manganese chloride $(0.025$ volumes of $1 \mathrm{M}$ $\mathrm{MnCl}_{2}$ ) was added to the supernatant with rapid stirring and the precipitate formed was removed by centrifugation. The clarified supernatant thus obtained was centrifuged at $120000 \mathrm{~g}$ for 5 hours in a Beckman model L5/75 ultracentrifuge. This caused the enzyme to concentrate at the bottom of the centrifuge tube as illustrated in Fig. 1. The fractions containing the highest acetyl $\mathrm{CoA}$ carboxylase activity were collected, diluted (1:6 fold) with the homogenization buffer and recentrifuged for further 5 hours at the same speed. This

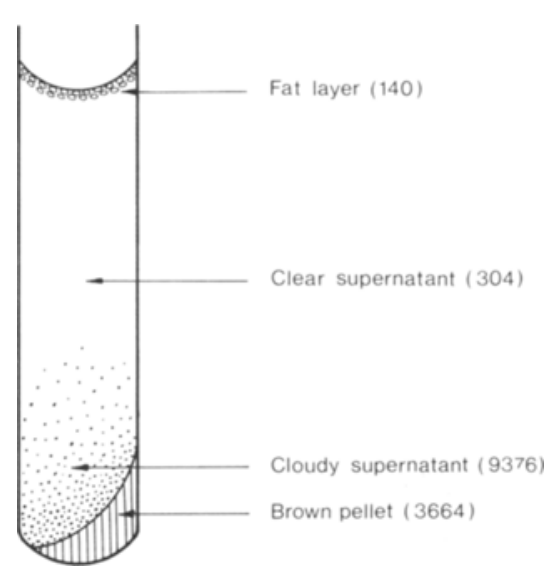

Figure 1. Distribution of acetyl CoA carboxylase activity in the tube after ultracentrifugation.

A $\mathrm{MnCl}_{2}$ treated extract of barley embryos in $55 \mathrm{mM}$ imidazole buffer $\mathrm{pH} 8.3$ containing $1 \mathrm{mM}$ dithiothreitol was centrifuged for 5 hours at $120000 \mathrm{~g}$ and $4^{\circ} \mathrm{C}$. The numbers in brackets refer to carboxylase activity given as ${ }^{14} \mathrm{CO}_{2}(\mathrm{cpm})$ fixed/min/mg protein. 
procedure was repeated twice more. The enzyme preparation was then loaded onto a sepharose $6 \mathrm{~B}$ column $(40 \times 2.5 \mathrm{~cm})$. Elution was carried out with $55 \mathrm{mM}$ imidazole buffer pH 8.0 containing $1 \mathrm{mM}$ dithiothreitol and $1 \%$ $\mathrm{NaCl}$. Fractions $(2.6 \mathrm{ml})$ were collected from the column and assayed for carboxylase activity. All procedures of extraction and purification were carried out at $0-4^{\circ} \mathrm{C}$.

\subsection{Acetyl CoA carboxylase assay}

The reaction mixture (total volume $0.5 \mathrm{ml}$ ) contained the following in $\mu$ moles: Tris- $\mathrm{HCl}$ buffer $\mathrm{pH} 8.3,0.05$; ATP, 2.5; $\mathrm{MgCl}_{2}, 5.0 ; \mathrm{MnCl}_{2}, 0.5$; dithiothreitol, 1.0 ; acetyl $\mathrm{CoA}, 0.15 ; \mathrm{NaH}^{14} \mathrm{CO}_{3}$, $1.17(3 \mu \mathrm{Ci})$. The amount of enzyme used in an assay varied from $20-200 \mu \mathrm{g}$ protein. Control tubes were set up for each assay by omitting acetyl $\mathrm{CoA}$. Incubations were carried out at $30^{\circ} \mathrm{C}$ for $20 \mathrm{~min}$. The reactions were terminated by adding $0.2 \mathrm{ml}$ of conc. $\mathrm{HCl}$. Aliquots $(50 \mu \mathrm{l})$ were placed on filter paper discs and dried for $20 \mathrm{~min}$. at $80^{\circ} \mathrm{C}$. Acid stable radioactivity on filter paper discs was counted in a Packard model 2002 Tricarb scintillation spectrometer using $10 \mathrm{ml}$ of Packard's "Dimilume" scintillation fluid. Acid stable radioactivity observed in the control tubes was subtracted from the values obtained in the respective test tubes to determine ${ }^{14} \mathrm{CO}_{2}$ fixation due to acetyl $\mathrm{CoA}$ carboxylase activity.

\subsection{Other assays}

Biotin was measured by the method of GREEN (4), while protein was estimated by the FolinCiacalteau technique of LoWRY et al. (14). Biotin carboxyl carrier protein was assayed as described previously $(11,12,13)$.

Polyacrylamide disc gel electrophoresis in an asparagine system was performed according to HEDRICK and SMITH (9) and phenol: acetic acid: urea disc gel electrophoresis according to NiELSEN (20).

\subsection{Electron microscopy}

The method of VALENTINE et al. (23) was employed to examine molecules of acetyl CoA carboxylase in the electron microscope. The purified enzyme was adsorbed on carbon films prepared on cleaved mica and negatively stained with sodium silicotungstate $(5 \% \mathrm{w} / \mathrm{v})$ at $\mathrm{pH} 7.0$ for $2.4 \mathrm{~min}$ at room temperature. The films were mounted on copper grids and studied in a Siemens Elmiskop 102. Pictures were taken at a magnification of 50000 .

\subsection{Chemicals}

Avidin, ATP, Coenzyme A and dithiothreitol were obtained from Sigma Chemical Company St. Louis, Mo., U.S.A. Sodium ${ }^{14} \mathrm{C}$ bicarbonate was obtained from Radio Chemical Centre, Amersham, U. K. Acetyl CoA was prepared from acetic anhydride and coenzyme $A$ according to SimON and SHEMIN (22). Biotin carboxylase and transcarboxylase were obtained from Escherichia coli according to the method of NERvi et al. (19).

\section{RESULTS AND DISCUSSION}

The purity of barley embryo acetyl CoA carboxylase obtained by the two methods employed is illustrated in Tables I and II. Both procedures resulted in protein fractions with closely similar specific enzymatic activities ( 7 to $7.4 \mu$ moles of $\mathrm{Co}_{2}$ fixed per min per mg protein). However, the enzyme could be purified faster by repeated ultracentrifugation than by the procedure described by HEINSTEIN and STUMPF (10). With both methods the yield of purified enzyme varied considerably from one experiment to another. This variability was in part due to the condition of the embryos at the initial step of extraction. Thus, homogenates made rom fresh embryos contained enzyme at a specific activity of 0.0025 to $0.0030 \mu$ moles $\mathrm{CO}_{2}$ fixed $/ \mathrm{min} / \mathrm{mg}$ protein, whereas extracts made from embryos which had been frozen and stored for 7 days gave specific activities of approximately $0.001 \mu$ moles $\mathrm{CO}_{2}$ fixed $/ \mathrm{min} / \mathrm{mg}$ protein. Subjecting the enzyme preparation to DEAE cellulose chromatography, sephadex $G$ 200 and sepharose $6 \mathrm{~B}$ gel filtration produced no change in the specific activity of the preparation. The evidence presented below suggests a high purity of the enzyme in these preparations. Polyacrylamide disc gel electrophoresis of purified enzyme in the asparagine system of HEDRICK and SMITH (9) caused a complete loss of enzyme activity and five protein bands 
Table I

Purification of acetyl CoA carboxylase from barley according to the method described by HEINSTEIN and STUMPF (10). The enzyme was extracted from embroys that had been stored frozen at $-20^{\circ} \mathrm{C}$. The activation was performed by preliminary incubation of the protein for $60 \mathrm{~min}$ at $30^{\circ} \mathrm{C}$ with $0.01 \mathrm{M}$ dithiothreitol and $0.25 \mathrm{M}$ phosphate buffer $\mathrm{pH} 8.0$.

\begin{tabular}{|c|c|c|c|}
\hline Fraction & $\begin{array}{c}\text { Total protein } \\
\text { mg }\end{array}$ & $\begin{array}{c}\text { Specific activity } \\
\mu \text { moles } \mathrm{CO}_{2} \text { fixed } / \mathrm{min} / \mathrm{mg} \\
\text { protein }\end{array}$ & $\begin{array}{c}\text { Recovery } \\
\%\end{array}$ \\
\hline $\begin{array}{l}\text { 1. Extract } \\
\text { 2. } \mathrm{MnCl}_{2} \text { supernatant } \\
\text { 3. }\left(\mathrm{NH}_{4}\right)_{2} \mathrm{SO}_{4}(0.28-0.38 \text { saturation }) \\
\text { 4. DEAE cellulose } \\
\text { 5. DEAE sephadex A } 50 \\
\text { 6. Sucrose gradient } \\
\text { centrifugation } \\
\text { 7. Activation }\end{array}$ & $\begin{array}{r}70890 \\
15614 \\
5246 \\
19.0 \\
10.4 \\
\\
1.06 \\
1.06\end{array}$ & $\begin{array}{l}0.001 \\
0.004 \\
0.01 \\
0.8 \\
1.4 \\
6.9 \\
7.1\end{array}$ & $\begin{array}{l}100 \\
88.1 \\
74.0 \\
21.4 \\
20.6 \\
10.3 \\
10.6\end{array}$ \\
\hline
\end{tabular}

appeared in the gels in agreement with the situation encountered by HEINSTEIN and STUMPF with an over 1000 fold purified preparation of wheat germ acetyl CoA carboxylase. The latter authors showed by studying the individual protein bands for biotin content, ATP${ }^{32} \mathrm{Pi}$ exchange and malonyl $\mathrm{CoA}$-acetyl $\mathrm{CoA}$ exchange that all five protein bands had activities ascribable to wheat germ acetyl CoA carboxylase. The polyacrylamide disc gel electrophoretic pattern of barley embryo acetyl $\mathrm{CoA}$ carboxylase in the phenol: acetic acid: urea system is shown in Fig. 2. Three polypeptide bands with relative mobilities of $0.44,0.53$ and 0.66 were observed in the gels. In order of their increasing relative mobility these bands corresponded to apparent molecular weights of 41000,32000 and 21000 daltons respectively. Proteins corresponding to the individual bands were eluted from unstained gels and analysed for their biotin content and enzyme activities. None of the protein fractions obtained showed any acetyl $\mathrm{CoA}$ carboxylase, biotin carboxylase or transcarboxylase activities. Attempts to reconstitute these enzyme activities by combining different protein fractions were also unseccessful. The protein corresponding to a relative mobility of 0.66 contained $10.1 \pm 2.2 \mu \mathrm{g}$ biotin/mg protein and was able to function as carboxyl carrier in the $E$. coli acetyl CoA

\section{Table II}

Purificaton of barley embryo acetyl CoA carboxylase by repeated ultracentrifugation.

The enzyme was extracted from freshly obtained embryos.

\begin{tabular}{l|c|c|c}
\hline Fraction & $\begin{array}{c}\text { Total protein } \\
\mathrm{mg}\end{array}$ & $\begin{array}{c}\text { Specific activity } \\
\mu \text { moles } \mathrm{CO}_{2} \text { fixed/min/mg } \\
\text { protein }\end{array}$ & $\begin{array}{c}\text { Recovery } \\
\%\end{array}$ \\
\hline 1. Extract & 7080 & 0.003 & 100 \\
2. $\mathrm{MnCl}_{2}$ supernatant & 1493 & 0.01 & 70.3 \\
3. 1st ultracentrifugation & 13.8 & 0.9 & 58.5 \\
4. 2nd ultracentrifugation & 1.6 & 5.0 & 37.7 \\
5. 3rd ultracentrifugation & 0.6 & 7.3 & 20.6 \\
6. 4th ultracentrifugation & 0.54 & 7.4 & 18.8 \\
7. Sepharose 6B & 0.49 & 7.4 & 17.1 \\
\hline
\end{tabular}




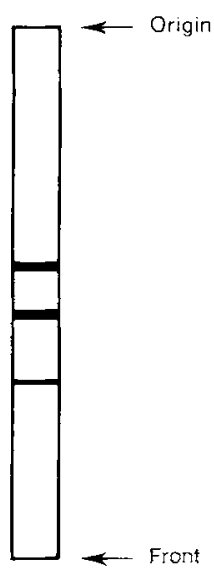

Figure 2. Disc gel electrophoretic pattern of barley embryo acetyl CoA carboxylase.

The purified enzyme was electrophoresed for 6 hours at room temperature in a polyacrylamide gel using the phenol: acetid acid: $8 \mathrm{M}$ urea (2:1:1 by vol) system as described by NIELSEN (20). The gels were stained with $1 \%$ amido black in $7 \%$ acetid acid.

carboxylase reaction (Table III) in the same way as the corresponding polypeptide from the chloroplast acetyl CoA carboxylase (cf. 13). In the other two protein fractions obtained from the gels biotin could not be detected. Acetyl CoA carboxylase $(400 \mu \mathrm{g})$ purified from barley embryos gave an unstable carboxylated enzyme when incubated with all the cofactors except CoA (Table IV). Addition of acetyl CoA to carboxylated enzyme resulted in a rapid formation of labelled malonyl CoA. Therefore we concluded that in addition to biotin carboxyl carrier protein both biotin carboxylase and transcarboxylase activities are associated with the purified barley embryo acetyl CoA carboxylase. Phenol: acetid acid: urea allowed only biotin carboxyl carrier protein to be obtained in an active form. The biotin containing polypeptide isolated from the soluble embryo acetyl CoA carboxylase shows similarities to barley chloroplast biotinyl protein both in function and in behaviour during disc gel electrophoresis. The behaviour of purified barley embryo acetyl CoA carboxylase in sepharose $6 \mathrm{~B}$ gel filtration chromatography as illustrated in Figs. 3 and 4 reveals molecular aggregation. The enzyme was excluded as a single protein peak from sepharose 6B when eluted with $55 \mathrm{mM}$ imidazole buffer $\mathrm{pH} 8.0$

\section{Table III}

Evidence for the participation of the biotinyl peptide isolated from barley embryo acetyl CoA carboxylase in the Escherichia coli acetyl CoA carboxylase reaction.

The complete reaction mixture contained in a total volume of $1.0 \mathrm{ml}$ the following: $55 \mathrm{mM}$ imidazole $\mathrm{HCl}$ buffer $\mathrm{pH} 8.0, \mathrm{mM}$ dithiothreitol, $0.5 \mathrm{mM} \mathrm{MnCl}, 0.5$ $\mathrm{mM} \mathrm{MgCl}, 2 \mathrm{mM} \mathrm{ATP}, 0.17 \mathrm{mM} \mathrm{NaH}{ }^{14} \mathrm{CO}_{3}(10 \mu \mathrm{Ci})$, $0.4 \mathrm{mM}$ acetyl $\mathrm{CoA}, 0.9 \mathrm{mg}$ E.coli transcarboxylase, $0.4 \mathrm{mg}$ E.coli biotin carboxylase and $14 \mu \mathrm{g}$ of biotinyl peptide.

Incubations were carried out at $30^{\circ} \mathrm{C}$ for $30 \mathrm{~min}$. and terminated by the addition of $200 \mu \mathrm{l}$ of concentrated $\mathrm{HCl}$. Aliquots were placed on filter paper discs dried and acid stable radioactivity determined.

Reaction mixture

Acid stable radioactivity (cpm fixed into malonyl $\mathrm{CoA}$ )

\begin{tabular}{l|r}
\hline Complete & 2984 \\
- biotinyl peptide & 484 \\
- E.coli biotin carboxylase & 16 \\
- E.coli transcarboxylase & 12 \\
\hline
\end{tabular}

\section{Table IV}

Formation enzyme- ${ }^{14} \mathrm{CO}_{2}$ complex and transfer of ${ }^{14} \mathrm{CO}_{2}$ to malonyl CoA.

The complete reaction mixture contained in $1.0 \mathrm{ml}$ the following: $55 \mathrm{mM}$ imidazole $\mathrm{HCl}$ buffer $\mathrm{pH} 8.0$, $0.5 \mathrm{mM} \mathrm{MgCl} 2,0.5 \mathrm{mM} \mathrm{MnCl}, 2 \mathrm{mM}$ ATP, $0.17 \mathrm{mM}$ $\mathrm{NaH}^{14} \mathrm{CO}_{3}(10 \mu \mathrm{Ci})$ and $400 \mu \mathrm{g}$ acetyl $\mathrm{CoA}$ carboxylase. The miture was incubated for $15 \mathrm{~min}$. at $30^{\circ} \mathrm{C}$ and applied on to a sephadex G-50 $(2 \times 30 \mathrm{~cm})$ column equilibrated with $55 \mathrm{mM}$ imidazole $\mathrm{HCl}$ buffer $\mathrm{pH}$ 8.0. Aliquots from the fractions containing protein were counted for radioactivity. The protein fractions $(1.5 \mathrm{ml})$ containing bound ${ }^{14} \mathrm{CO}_{2}(48300$ $\mathrm{cpm}$ ) were incubated with and without $0.4 \mathrm{mM}$ acetyl $\mathrm{CoA}$ for $30 \mathrm{~min}$. at $30^{\circ} \mathrm{C}$. Reactions were terminated by the addition of $200 \mu \mathrm{l}$ of concentrated $\mathrm{HCl}$ and acid stable radioactivity was determined after drying aliquots on filter paper discs.

\begin{tabular}{l|c}
\hline $\begin{array}{l}\text { Enzyme- }{ }^{14} \mathrm{CO}_{2} \text { complex } \\
\text { formation }\end{array}$ & $\begin{array}{c}{ }^{14} \mathrm{CO}_{2} \text { (cpm) bound } \\
\text { to protein }\end{array}$ \\
\hline $\begin{array}{l}\text { Complete } \\
\text { - Enzyme }\end{array}$ & 62260 \\
- ATP & 0 \\
\hline $\begin{array}{l}\text { Transfer of }{ }^{14} \mathrm{CO}_{2} \\
\text { to malonyl } \mathrm{CoA}\end{array}$ & 0 \\
\hline + Acetyl $\mathrm{CoA}$ & Acid stable \\
- Acetyl CoA & 30900 \\
\hline
\end{tabular}




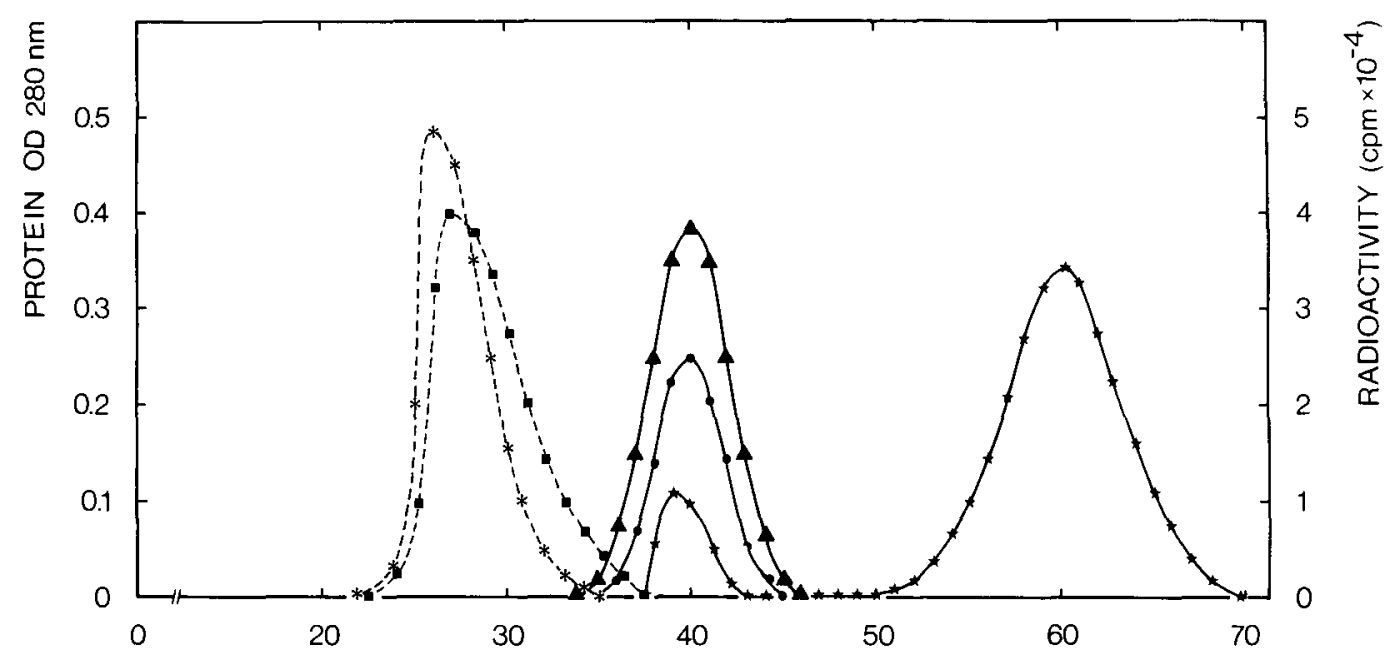

FRACTION NUMBER

Figure 3. The elution profiles of avidin treated and untreated barley embryo acetyl $\operatorname{CoA}$ carboxylase in a sepharose $6 B$ column $(40 \times 2.5 \mathrm{~cm})$.

Eluant contained $55 \mathrm{mM}$ imidazole buffer $\mathrm{pH} 8.0,1$ $\mathrm{mM}$ dithiothreitol with and without addition of $1 \%$ $(\mathrm{w} / \mathrm{v}) \mathrm{NaCl}$. The dotted lines show the profiles of protein (--- ---) and carboxylase activity $\left(---w_{---)}\right.$in the absence of $1 \% \mathrm{NaCl}$. The solid lines refer to protein (- - ), carboxylase activity $(--\longrightarrow)$ and avidin treated protein (- - profiles observed in the presence of $1 \% \mathrm{NaCl}$. The avidin treated enzyme (-_- - ) gave two uv light absorbing peaks. The first peak corresponds to the enzyme-avidin complex while the second larger peak represents free avidin.

containing $1 \mathrm{mM}$ dithiothreitol. Carboxylase activity was associated with the leading edge of the protein peak. The approximate exclusion limit for sepharose $6 \mathrm{~B}$ is a protein molecular weight $4 \times 10^{6}$ daltons. However, sepharose $6 \mathrm{~B}$ gel filtration of purified enzyme in the presence of $1 \%$ sodium chloride caused the protein molecules to penetrate the agarose beads. The enzyme was then eluted at a position corresponding to a molecular weight of 610000 daltons (Figs. 3 and 4). Carboxylase activity was associated uniformly throughout the peak. These data reveal that $1 \%$ sodium chloride under conditions used prevent aggregation of barley embryo acetyl CoA carboxylase. The purified enzyme contained $0.42 \pm 0.06 \mu \mathrm{g}$ biotin per $\mathrm{mg}$ protein which amounts to 1.05 moles of biotin per $610000 \mathrm{~g}$ of carboxylase. Thus it is concluded that the barley embryo enzyme has 1 mole of biotin per mole of enzyme. Since the biotin is covalently bound to the 21000 dalton peptide, each enzyme molecule contains a single biotinyl polypeptide. The egg white protein avidin (M.W. 63000) has the property of strongly and specifically binding to biotin. Avidin has four biotin binding sites localized in two fold symmetry (5). The purified enzyme (4 $\mathrm{mg}$ ) was treated with excess avidin $(6 \mathrm{mg})$ and subjected to sepharose $6 \mathrm{~B}$ gel filtration in the presence of $1 \% \mathrm{NaCl}$. This avidin treatment resulted in a $100 \%$ inhibition of the carboxylase activity of the enzyme. Both avidin treated and untreated barley embryo acetyl CoA carboxylase eluted very close to each other from the sepharose 6B column (Fig. 3). This reveals that under the conditions employed, excess of avidin and presence of $\mathrm{NaCl}$, a single avidin molecule did not bind more than a single carboxylase molecule. This result further supports the finding that only one biotin molecule is present per enzyme molecule as binding of several avidin molecules would have shifted the peak position measurably.

Acetyl CoA carboxylase purified from barley embryos was unstable. It lost over $50 \%$ of its activity during a week stored frozen in the presence of $50 \%$ saturated ammonium sulphate and $1.0 \mathrm{mM}$ dithiothreitol. The loss of enzyme activity was associated with an increase in turbidity of the preparation indicating protein aggregation. 


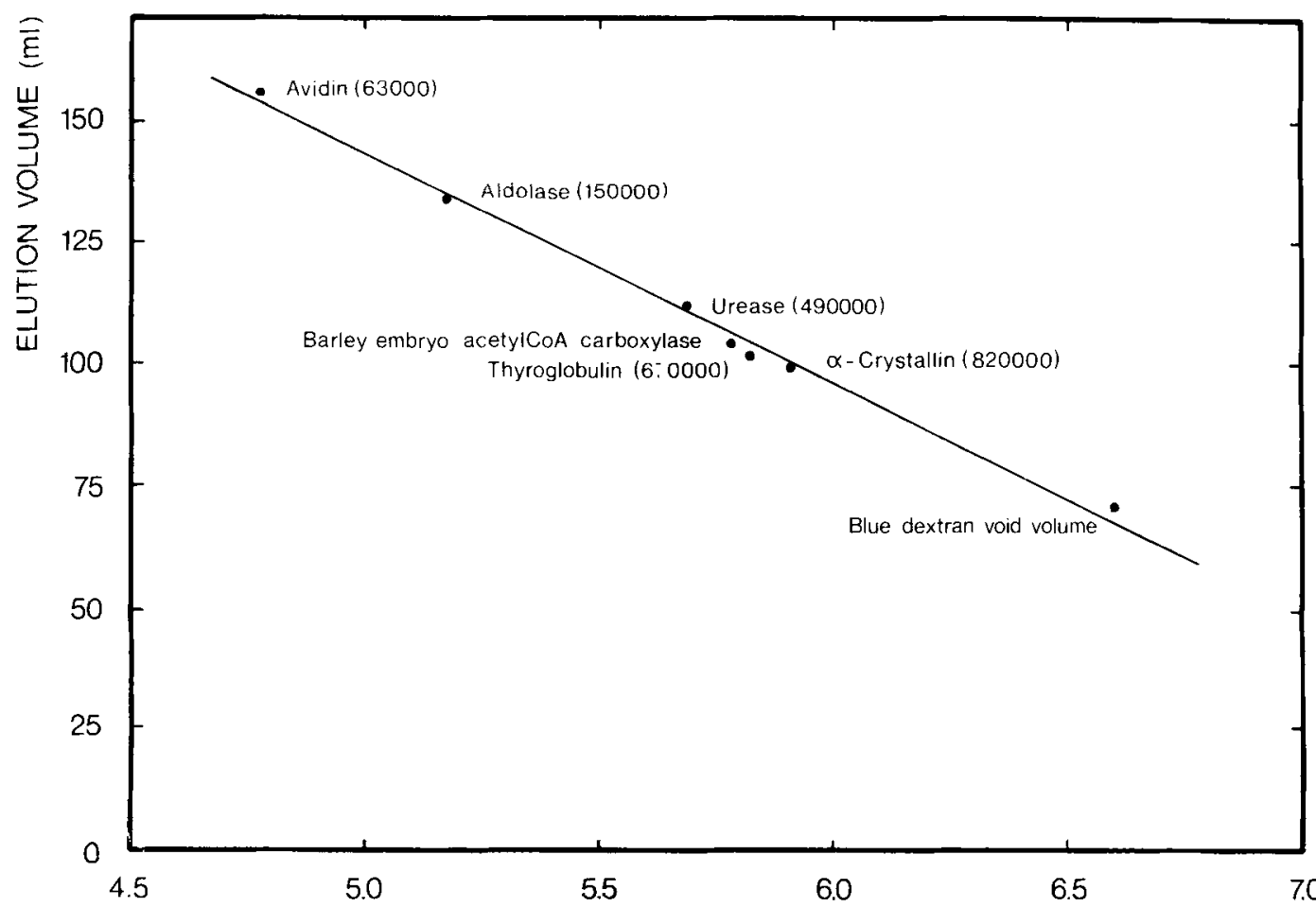

LOg MOLECULAR WEIGHT

Figure 4. The protein molecular weight calibration curve for the sepharose $6 B$ column $(40 \times 2.5 \mathrm{~cm})$.

The standard proteins were eluted with $55 \mathrm{mM}$ imidazole buffer $\mathrm{pH} 8.2$ containing $1 \mathrm{mM}$ dithiothreitol and $1 \%(\mathrm{w} / \mathrm{v}) \mathrm{NaCl}$ at $4^{\circ} \mathrm{C}$. The eluate was monitored for uv absorption at $254 \mathrm{~nm}$ using a LKB UVICORD II. The numbers within brackets refer to the molecular weights of the proteins in daltons. Barley embryo acetyl CoA carboxylase was eluted at a position corresponding to a molecular weight of 610000 daltons.

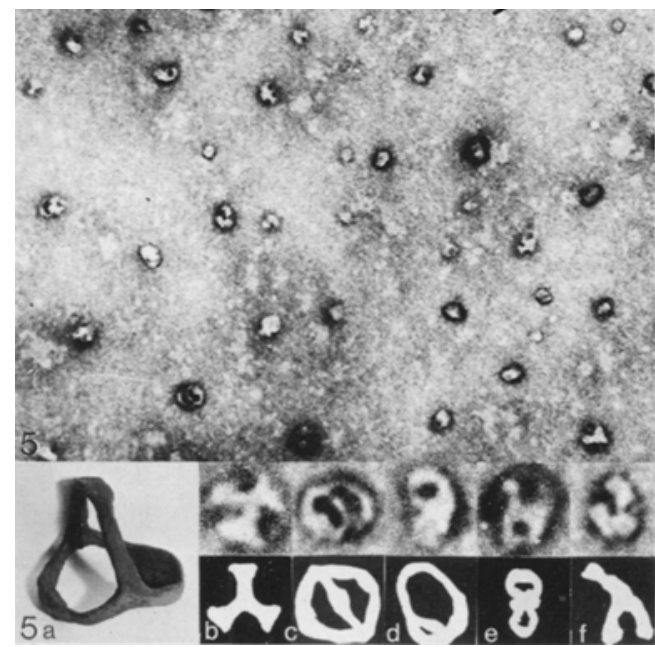

In electron micrographs of negative contrast preparations, the purified enzyme appeared as a globular protein. Measuring 90 particles on electron micrographs at a magnification of 400000 gave $275 \pm 8 \dot{A}$ for the longest visible diameter and $192 \pm 45 \AA$ for the shortest visible diameter (Fig. 5). A substructure is recognizable in the molecules. The stain penetrates into three cavities of the molecules which have an average diameter og 50-60 $\AA$. In cases where the protein material was recognizable between two adjacent cavities, it measured approximate-

Figure 5. Electron micrograph of purified barley embryo acetyl CoA carboxylase.

A carbon film freshly stripped from mica was floated on a solution of protein $(50 \mu \mathrm{g} / \mathrm{ml})$ as described by VALENTINE et al. (23). The molecules adsorbed on the film were negatively stained in $5 \%(\mathrm{w} / \mathrm{v})$ sodium silicotungstate $\mathrm{pH} 7.0$ for $4 \mathrm{~min}$. The preparation was studied in a Siemens Elmiskop 102 at a magnification of 50000 . The final magnification is 80000 . Fig. $5 a$ shows the proposed model for the molecule. Figs. $5 b$ to $5 f$ present five characteristic images of the carboxylase magnified 175000 fold together with a corresponding shadowgraph of the model in Fig. 5a. 
ly $55 \AA$ in thickness. A model that would fit the observed shapes of the molecule in the micrographs is depicted in Fig. 5a. In Figs. 5b to $5 f$ higher magnifications of some characteristic images of the carboxylase are presented together with the corresponding shadowgraphs of the model in Fig. 5a. Filament formation as is characteristic for the active liver enzyme has not been observed for barley embryo acetyl CoA carboxylase. The morphology of the barley embryo enzyme is in agreement with the biochemical characteristics of its active state as reported above.

\section{ACKNOWLEDGEMENT}

This investigation was supported in part by grants GM 10819 and GM 22051 from the U. S. Public Health Service, National Institutes of Health to Professor D. von WetTSTEIN. We would like to thank Professor DITER VON WETTSTEIN for helping us in the preparation of the manuscript. Helpful discussions with Professor PAUL K. STUMPF and Dr. SøREN RASMUSSEN as well as technical assistance from JEAN SAGE, PREBEN Holm, Barbro Strid, REBECCA STERN and ULLA EDEN are also gratefully acknowledged.

\section{REFERENCES}

1. Alberts, A. W. \& P. R. VAgelos: Acetyl CoA carboxylase, 1. Requirement for two protein fractions. Proc. Nati. Acad. Sci. U.S.A. 59: 561568 (1968).

2. Alberts, A.W. \& P. R. Vagelos: Acyl-CoA carboxylases. In: P. D. Boyer, ed., The Enzymes, 6, pp. 37-82. A cademic Press (New York) 1972.

3. Caldwell, F.: Overcoming dormancy in undamaged and damaged barley harvested in 1956. J. Inst. Brew. 63: 340-344 (1957).

4. GREen, N. M.: Spectrophotometric determination of avidin and biotin. $I n$ : McCormick and Wright, eds., Methods in Enzymology, 18A, pp. 418-424. Academic Press (New York) 1970.

5. Green, N. M., L. Konoeczny, E. J. Toms \& R. C. VALENTINE: The use of bifunctional biotinyl compounds to determine the arrangement of subunits in avidin. Biochem. J. 125: 781-791 (1971).
6. Gregolin, C., E. Ryder, R. C. WARner \& M. D. LANG: Molecular characteristics of liver acetyl CoA carboxylase. Proc. Natl. Acad. Sci. U.S.A. 56: 148-155 (1966).

7. Gregolin, C., E. Ryder, R. C. Warner \& M. D. LANG: Liver acetyl CoA carboxylase: The dissociation-reassociation process and its relation to catalytic activity. Proc. Natl. Acad. Sci. U.S.A. 56: 1751-1758 (1966).

8. HАтCH, M. D. \& P. K. StumpF: Fat metabolism in higher plants. XVI. Acetyl coenzyme A carboxylase and acyl coenzyme A - malonyl coenzyme A transcarboxylase from wheat germ. J. Biol. Chem. 236: 2879-2885 (1961).

9. Hedrick, J. L. \& A. J. SMITh: Size and charge isomer separation and estimation of molecular weights of proteins by disc gel electrophoresis. Arch. Biochem. Biophys. 126: 155-164 (1968).

10. Heinstein, P. F. \& P. K. Stumpf: Fat metabolism in higher plants. XXXVIII. Properties of wheat germ acetyl coenzyme A carboxylase. J. Biol. Chem. 244: 5374-5381 (1969).

11. Kannangara, C. G. \& P. K. StumpF: Fat metabolism in higher plants. LIV. A procaryotic type acetyl $\mathrm{CoA}$ carboxylase in spinach chloroplasts. Arch. Biochem. Biophys. 152: 83-91 (1972).

12. Kannangara, C. G. \& P. K. StumpF: Fat metabolism in higher plants. LVI. Distribution and nature of biotin in chloroplasts of different plant species. Arch. Biochem. Biophys. 155: 391 399 (1973).

13. Kannangara, C. G. \& C. J. Jensen: Biotin carboxyl carrier protein in barley chloroplast membranes. Eur. J. Biochem. 54: 25-30 (1975).

14. Lowry, D. H., N. J. Rosebrough, A. L. FARr \& R. J. Randall: Protein measurement with the folin phenol reagent. J. Biol. Chem. 193: 265-275 (1951).

15. Matsuhashi, M., S. Matsuhashi \& F. Lynen: Zur Biosynthese der Fettsäuren. V. Die AcetylCoA Carboxylase aus Rattenleber und Ihre Aktivierung durch Citronensäure. Biochem. Z. 340: 263-289 (1964).

16. Matsuhashi, M., S. Matsuhashi, S. Numa \& F. LYNEN: Zur Biosynthese der Fettsâuren. IV. Acetyl CoA Carboxylase aus Hefe. Biochem. $Z$. 340: 243-262 (1964).

17. Moss, J. \& M. D. LANE: The biotin-dependent enzymes. In: Meister, ed., Advances in Enzymology and Related Areas of Molecular Biology, 35, pp. 321-442. Interscience Publishers (New York) 1971 .

18. Murphy, G. J. P. \& D. E. Briggs: Gibberellin estimation and biosynthesis in germinating Hordeum distichon. Phytochem. 12: 1299-1308 (1972).

19. Nervi, A. M., A. W. Aalberts \& P. R. Vagelos: Acetyl CoA carboxylase. III. Purification and properties of a biotin carboxyl carrier protein. Arch. Biochem. Biophys. 143; 401-411 (1971).

20. NIELSEN, N. C.: Electrophoretic characterization 
of membrane proteins during chloroplast development in barley. Eur. J. Biochem. 50: 611-623 (1975).

21. Ryder, E., C. Gregolin, H. Chang \& M. D. LANE: Liver acetyl COA carboxylase: Insight into the mechanism of activation by tricarboxylic acids and acetyl CoA. Proc. Natl. Acad. Sci. U.S.A. 57: 1455-1462 (1967).
22. Simon, E. J. \& D. Shemin: The preparation of Ssuccinyl coenzyme A. J. Amer. Chem. Soc. 75: $2520(1953)$.

23. Valentine, R. C., B. M. Shapiro \& E. R. STADTMAN: Regulations of glutamine synthetase. XII. Electron microscopy of the enzyme from Escherichia coli. Biochemistry 7: 2143-2152 (1968). 